\title{
FOREWORD
}

\section{Unconventional Oil and Gas Development: Economic, Environmental, and Policy Analysis}

\section{J. Wesley Burnett}

In recent years, the United States has experienced a tremendous resurgence in hydrocarbon production, largely driven by recent technological advancements that have enabled natural gas and crude oil to be economically produced from shale and other low-permeability formations. In the process, the United States has become the world's largest producer of natural gas. According to British Petroleum's statistical world energy review, the United States has surpassed the Russian Federation in reaching a new all-time high of 688 billion cubic meters of produced natural gas in 2013 (British Petroleum 2014). At the same time, the United States overtook Saudi Arabia to become one of the largest crude oil producers in the world (Smith 2014)-U.S. output exceeded 11 million barrels per day during the first five months of 2014 (Energy Information Administration 2014a).

\section{Global and Domestic Impacts of U.S. Oil and Gas Development}

The development of shale gas and oil in the United States has fundamentally changed the global energy market. Prior to the mid-2000s, production of natural gas and oil in the United States had been on a slow decline after peaking in the early 1970s. As Figure 1 demonstrates, the shale revolution fundamentally changed those trends. Between 2005 and 2013, oil and natural gas production increased by approximately 44 percent and 35 percent, respectively, attributable mostly to shale, while production outside the United States has been relatively stable so far (Aguilera and Radetzki 2013).

The oil market is globally integrated so there is a single world price per quantity and quality. It is difficult to determine exactly how much impact the shale revolution has had on oil prices, but as of January 2015, U.S. prices of light crude fell below $\$ 50$ a barrel for the first time in nearly six years amid

\footnotetext{
J. Wesley Burnett is assistant professor in the Economics Department at the College of Charleston, South Carolina. Correspondence: J. Wesley Burnett - Economics Department * College of Charleston - 5 Liberty Street - Beatty Center, Suite 413 - Charleston, SC 29401 - Phone 843.953.0752 * Email burnettjw@cofc.edu.

This special issue of Agricultural and Resource Economics relates to the workshop "Unconventional Gas and Oil Development: Economic and Environmental Impacts" organized by the Northeastern Agricultural and Resource Economics Association and held in Morgantown, West Virginia, on June 3 and 4, 2014. The authors and editors acknowledge and thank the National Agricultural and Rural Development Policy Center and the U.S. Department of Agriculture National Institute of Food and Agriculture for funding under competitive grant 2012-70002-1938. Additional support was provide by the Davis College of Agriculture, Natural Resources, and Design's Office of Sponsored Programs and the Regional Research Institute, both of West Virginia University. The views expressed are the authors' and do not necessarily represent the policies or views of any sponsoring agencies.
} 


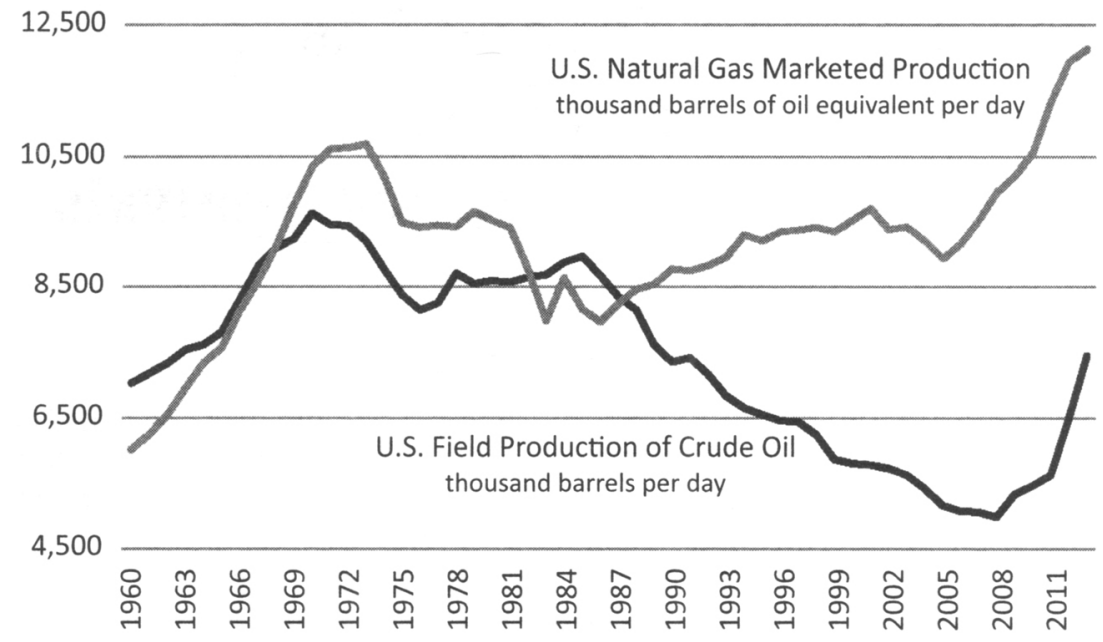

\section{Figure 1. U.S. Daily Natural Gas and Oil Production}

Note: The data were downloaded from the U.S. Energy Information Administration (2014b, 2014c), and the conversions of cubic feet of natural gas production to barrels of oil equivalent were performed by the author.

mounting fear among producers that the market will remain awash in crude for the foreseeable future (Friedman 2015). The decline in prices is not entirely attributed to U.S. shale production; economies in Europe and Asia have continued to struggle and those nations have consumed less crude than expected. Over the last several decades, Saudi Arabia has played the role of swing producer-a supplier of crude oil that possesses substantial spare production capacity and, as a result, can increase or decrease supply at a minimum cost and thus influence prices and the balance in markets (Griffin and Neilson 1994). At the moment, however, it appears that the excess shortrun crude supply coming from the United States has robbed Saudi Arabia of that power, and some analysts are predicting further near-term slides in global crude prices (Friedman 2015). Other analysts have argued that Saudi Arabia is strategically allowing the slide in crude oil prices by not cutting its production to see how long American producers can pump shale oil profitably (Solomon and Said 2014). Meanwhile, U.S. auto drivers are enjoying low gasoline prices; the national average retail price fell below \$2.20 per gallon in January 2015 . Analysts predict that, if gasoline prices remain this low through 2015, American households can save an average of $\$ 400$ per month (Schwartz, Krauss, and Searcey 2014). With downward pressure on crude prices, core inflation is also expected to remain low in the coming year, which may further stimulate the national economy and enhance job growth following the 2008 recession.

Economists and energy analysts have long recognized the tie (cointegration) between prices for crude oil and natural gas. Their prices often deviate in the short run because natural gas prices tend to be more volatile (Ramberg and Parsons 2012). Therefore, since global crude prices are trending downward, the same is expected for natural gas prices. However, one can argue that natural gas markets are not globally integrated under a single world price so there is considerable variation in domestic natural gas prices across countries. In the United States, wellhead prices for natural gas have been declining since reaching a peak in 2008 at approximately $\$ 10$ per thousand cubic feet. 
The price bottomed out at less than $\$ 2$ in May 2012 and rebounded slightly thereafter (Energy Information Administration 2014d). Figure 2 compares annual average prices for natural gas for the United States, Europe, and Japan. In 2014, the price in the United States was 57 percent less than the price in Europe and 72 percent less than the price in Japan. Hence, there have been significant arbitrage opportunities among these markets, which explains why the U.S. Department of Energy received more than 40 applications in 2014 alone to build export facilities for liquid natural gas (Department of Energy 2014).

In addition to reducing energy prices, resurgence of the petroleum industry in the United States has provided a financial boon by creating jobs (Weber 2012, 2014), generating tax revenue for state and local governments (Raimi and Newell 2014), and boosting local economies (Weber, Burnett, and Xiarchos 2014). Weber (2012), for example, found that natural gas development had led to a 1.5 percent annualized increase in employment at a county level in Colorado, Texas, and Wyoming. Furthermore, Weber (2014) found that natural gas production in the south-central United States appears not to have led to a "resource curse" in which areas that are relatively dependent on natural resources grow more slowly because of overinvestment in development of the resource. The study found that each gas-related mining job created more than one non-mining job in the 2000s and that production activities thus did not appear to be crowding out other industries. In a later study, Weber, Burnett, and Xiarchos (2014) found that housing values in areas of natural gas development around Dallas and Fort Worth, Texas, appreciated faster than housing values in nonshale areas of the same metropolitan statistical area. In addition, the shale areas retained a housing-value advantage even after drilling declined. The study presents evidence that the greater appreciation in value reflects property taxes imposed on producing oil and gas wells, which created a relationship between drilling and the property tax base that funds local schools and governments.

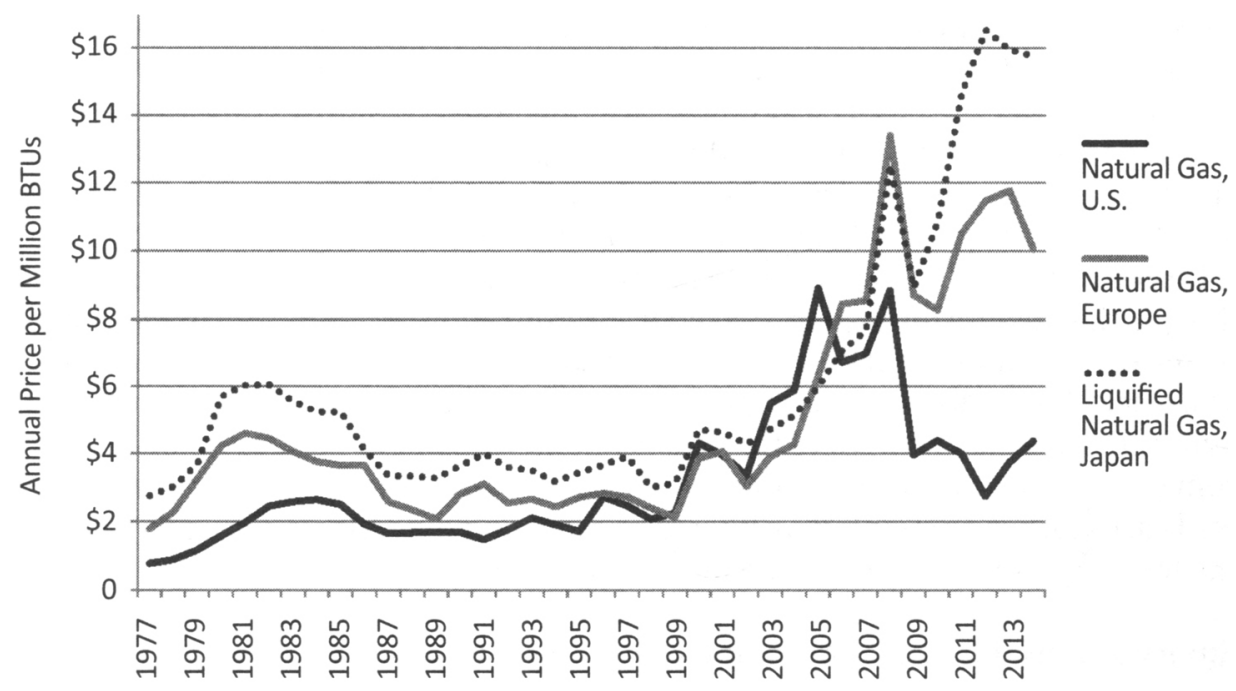

Figure 2. Natural Gas Prices in United States, Europe, and Japan

Note: The data were obtained from the World Bank (2014). 
Indeed, their study shows that a decline in the property tax rate and an increase in school revenue accompanied the increase in the tax base.

There is tremendous heterogeneity in the local impacts of unconventional oil and gas development across states due to differing state and local policies. For example, Munasib and Rickman (2015) used a natural experiment (a synthetic control method) to examine the net economic impacts of such development for regions in Arkansas, North Dakota, and Pennsylvania. They found significant positive impacts (measured as total employment, wage and salary employment, per capita income, the poverty rate, and population) for all of North Dakota's unconventional oil and gas producing counties but positive impacts only in a localized four-county region around development in Arkansas. In general, they found no statistically significant positive effects for Pennsylvania.

Research by Raimi and Newell (2014) implied that much of the heterogeneity comes from variation in state, county, and municipal government policies. They found net positive fiscal outcomes for governments in regions in which there was significant drilling and hydraulic fracturing activity. Much of the positive outcome was driven by increases in local tax receipts from property taxes levied on oil and gas production. The authors also found that increases in economic activity associated with oil and natural gas development had boosted sales tax revenue for local governments and municipalities. However, for some rural regions that experienced a rapid oil and gas boom, the net fiscal effect for local governments was negative.

\section{What Are Unconventional Fossil Fuels?}

Unconventional oil and natural gas deposits provide the same hydrocarbons as conventional deposits. The only differences are the geophysical conditions in which the resources are found and how they are extracted. Conventional oil and gas typically come from permeable rock formations that allow the oil and gas to escape freely after drilling of vertical wells. Unconventional oil and gas supplies are trapped in relatively impermeable rock formations such as shales, tight sands, carbonates, and coal beds. These types of formations generally have to be "fractured" before they release oil and/or gas in commercial quantities. Hydraulic fracturing ("fracking") is a process in which water and sand and sometimes other chemicals are injected at high pressure to fracture the impermeable rock, allowing the oil and gas compounds to enter the well. Fracturing generally involves a large volume of water-between 2 million and 5 million gallons per well (Environmental Protection Agency 2011).

Directional drilling of nonvertical, horizontal wells is a separate process, though the two technologies are most often used in tandem. Unconventional resources often are trapped in long horizontal seams paralleling the surface as depicted in Figure 3. Directional and horizontal drilling allows producers to bore wells along the length of the seams and thus produce greater quantities. In conventional vertical wells, geologic pressure releases the resources. Horizontal wells are further stimulated by injecting fracturing fluid into the bore to release the hydrocarbons trapped in the formation.

\section{Environmental Impacts Associated with Hydraulic Fracturing}

In addition to economic benefits, the shale gas revolution poses potential long-term threats to the quality of local water, air, land, and human health 


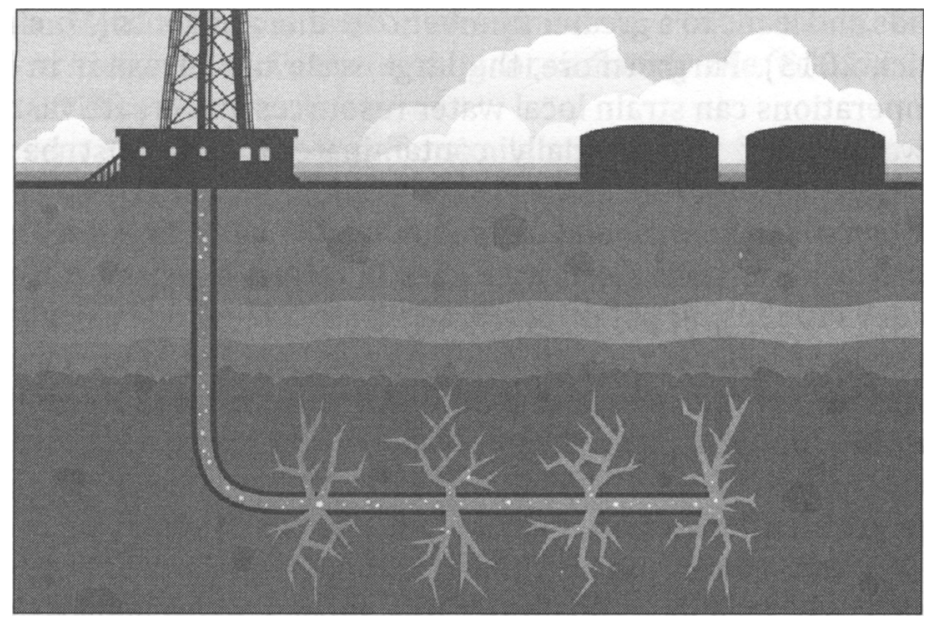

Figure 3. Directional Drilling and Hydraulic Fracturing

Note: Diagram obtained from Burnett (2013).

and to the overall quality of life in communities where it occurs. Consider the documentary "Gasland," which famously captured a Pennsylvania homeowner setting the water from his kitchen faucet on fire. Whether hydraulic fracturing contaminated the homeowner's water is a matter of debate. What is known is that the fluid used in hydraulic fracturing is composed mostly of water and sand (98-99 percent) but can also contain potentially hazardous and carcinogenic chemicals, including benzene and lead (Burnett 2013). The mere potential for contamination of ground and surface water convinced the state of New York to impose a moratorium on hydraulic fracturing and horizontal drilling. State regulators claimed that data regarding potential health and environmental risks associated with fracking were insufficient and therefore extended the moratorium indefinitely (Robinson 2014).

Unlike previous energy booms associated with offshore oil or the sparsely populated north slope of Alaska, the current energy boom is more disruptive; it is taking place in our backyards in the lower 48 states (Burnett and Weber 2014). Over the last decade, the industry has drilled thousands of new wells all across the country. The wells require an extensive new infrastructure to move, process, and deliver the oil and natural gas produced, and in many cases, they bring industrial infrastructures to otherwise bucolic landscapes.

Unconventional production of oil and gas has been linked to an increased risk of cancer and birth defects in surrounding areas and to increases in seismic activity. Macey et al. (2014), for example, found evidence of volatile compounds and other hazardous air pollutants near such sites. They concluded that the activities could lead to elevations in occurrences of cancer in the future since cancers often have latency periods of five to fifteen years (Neuhauser 2014). Hill (2013) found that local natural gas development is associated with lower birth weights in babies. Skoumal, Brudzinski, and Currie (2015) identified an association between unconventional natural gas development and more frequent seismic activity in northeast Ohio.

In addition to long-term risks, shale development imposes several nuisances on rural communities where it occurs, including heavy truck traffic that 
damage roads and leads to a greater number of traffic accidents (Muehlenbachs and Krupnick 2013). Furthermore, the large-scale use of water in hydraulic fracturing operations can strain local water resources and create vast amounts of waste water (that is potentially contaminated) that must be properly disposed.

Weak industry safeguards and inadequate oversight by state regulatory agencies could lead to severe consequences in terms of contaminated and/or depleted water supplies, air pollution, damaged streams, and marred landscapes (Natural Resources Defense Council 2009). Consequently, the magnitude of the economic benefits of unconventional oil and gas development are important counter-considerations.

\section{The Papers in this Special Issue}

This special issue arguably constitutes the most comprehensive economic assessment to date of unconventional oil and natural gas development. The post-conference workshop hosted by the Northeastern Agricultural and Resource Economics Association (NAREA) convened some of the top scholars of the economics of shale gas. As such, this issue of Agricultural and Resource Economics Review contains cutting-edge research on the topic.

Because shale-gas extraction is a relatively new development, the papers in this issue cover a wide variety of topics. Broadly, they can be characterized as analyzing economic impacts, environmental impacts, and policies-with considerable overlap as it is difficult to place any individual paper into only one group. Nevertheless, for purposes of exposition, we present each of the papers according to this categorization.

\section{Analysis of Economic Impacts}

The economic impacts of shale gas development are perhaps the most discussed and the most controversial. With access to capable software such as IMPLAN ${ }^{1}$ and appropriate economic data, it is relatively straightforward to generate assessments of the economic impacts of shale gas development. The popular press and special interest groups that support the industry have been quick to cite such assessments without vetting their quality or sources. Careful researchers who are not subject to the same tight deadlines as journalists often err on the side of caution and accuracy when presenting the results of those estimates, and peer-reviewed reports and assessments arguably have been vetted and therefore are published by reputable sources.

\section{Impacts on Job and Wage Growth}

Two past studies (or assessments) have been controversial: Considine, Watson, and Blumsack $(2010,2011)$ issued early estimates of the employment and wage

1 IMPLAN $^{\circledR}$ is software developed by MIG, Inc. that uses economic input-output analysis along with social accounting matrices and multiplier models to generate economic assessments of local or regional economies (e.g., a municipality, city, county, or state). The IMPLAN database consists of economic statistics at county, state, zip-code, and federal levels. Data selection can be customized to provide regional data sets, and the model can be used to measure effects (including multiplier effects) on a regional or local economy given a change or event in the economy's activity (MIG, Inc. 2015). 
impacts associated with shale gas development in Pennsylvania. The studies have been criticized as overestimating or inflating the economic impacts (Kinnaman 2011).

In the current issue, two papers offer similar criticisms of those past estimates, which were not necessarily subject to the rigor of the peer-review process. The first paper, "Resident vs. Nonresident Employment Associated with Marcellus Shale Development" by Douglas Wrenn, Timothy Kelsey, and Edward Jaenicke (2015), disputes the number of jobs the industry has created in Pennsylvania. The authors exploit income tax data for Pennsylvania and a quasi-experimental method (difference-in-difference-in-differences) to more accurately measure the number of jobs created by Pennsylvania's shale gas boom. They find that the number of jobs created is roughly half of what was previously reported.

In the second paper, "The Economic Impact of Shale Gas Development: A Natural Experiment along the New York / Pennsylvania Border," Brendan Cosgrove, Daniel LaFave, Sahan Dissanayake, and Michael Donihue (2015) take advantage of New York's 2008 statewide moratorium on hydraulic fracturing to analyze job and wage growth associated with the boom in shale gas development in Pennsylvania and use concurrent job and wage growth in New York as the counterfactual. They find a positive impact on employment and wages in the local natural resource, mining, and construction sectors but also a small offsetting reduction in employment in the manufacturing sector.

Both of these papers suggest caution in using input-output analyses to estimate the impacts of shale gas development.

\section{Impacts on Real Property Values}

Another method by which the economic impacts can be estimated is hedonic price analysis, which is based on the theory of revealed preference. It estimates demand or value by decomposing an economic good into various characteristics that economic agents demand. For example, demand for a house generally is not based solely on owning a piece of property. Instead, each property offers a bundle of characteristics-a number of bedrooms and bathrooms, of square feet of living space, and of square feet or acres of lot size plus other characteristics, such as the desirability of the neighborhood. Hedonic price analysis uses econometrics or regression analyses to obtain estimates of the contributory value of each of the demanded characteristics. In other words, the theory assumes that an economic good's value can be reduced to constituent parts that each have a market value (Rosen 1974).

Two studies in this special issue use hedonic price analyses based on private real estate values to measure the economic impacts of shale gas development. Under the hedonic price theory, the value of private real estate (i.e., home values) can be decomposed into its constituent characteristics, and the value may take nearby shale gas development into account. In other words, shale gas activity in close proximity to a private real estate property would be capitalized into the value of the property, and this effect would be revealed in the demand (market price) for the property.

In the first study, "What Can We Learn about Shale Gas Development from Land Values? Opportunities, Challenges, and Evidence from Texas and Pennsylvania," Jeremy Weber and Claudia Hitaj (2015) analyze impacts of shale gas development on farm real estate values, making an important contribution to the literature since most current shale gas development occurs in rural 
areas. The authors focus on two of the most prominent U.S. shale gas plays: the Marcellus and the Barnett. The study is unique in using quantile regression to tease out heterogeneous effects that likely reflect whether the subsurface mineral rights have been severed from surface ownership. Moreover, they estimate the average effects on farm real estate at different phases of development of the shale. The authors find that development in Pennsylvania caused greater appreciation for whole-estate farms than for split-estate farms. They also find that most of the appreciation in farm real estate value occurred during the leasing period and that the initial levels of appreciation persisted through the drilling period.

In a separate study, "Quantifying the Effects of Underground Natural Gas Storage on Nearby Residents," Michaela Jellicoe and Michael Delgado (2015) measure impacts associated with underground natural gas storage on local real estate values in Indiana. The existing literature has implicitly explored active and ongoing shale gas development but has not examined passive activities such as storage, which generally occur after extraction. The authors use data from a sample of Indiana properties for 2004 through 2013. They find that underground natural gas storage in general and observation wells in particular reduce a property's value and that the impact diminishes with every kilometer of distance away from a well. Like Muehlenbachs, Spiller, and Timmins (2014), the authors find, among other things, that a property without access to public water experiences a decrease in value of approximately $\$ 1,250$, on average, for each additional storage well.

\section{Impacts on Shale Gas Development}

The study by Timothy Fitzgerald (2015), "Experiential Gains with a New Technology: An Empirical Investigation of Hydraulic Fracturing," is an economic analysis deserving of its own subcategory. The subsection title may seem tautological. But as the author points out, the very act of developing shale gas resources can stimulate future development of such resources through experience with fracturing and hydraulic drilling and advances in technology associated with that learning. Fitzgerald uses well-level completion data, which provide job-specific information on fracturing, for wells in the Williston Basin of North Dakota and Montana to examine experiential learning during production and the role of undisclosed additives in the learning process. The study focuses on the ability of firms to improve production over the course of time and through collaboration. The results suggest that gains in production are associated with experience with fracking. In addition, the author finds that trade secret provisions that protect the identity of additives in a firm's hydraulic fracturing fluid are not correlated with increased production.

An important contribution of this paper is not stated explicitly. It emphasizes the small number of studies of the economics of production of shale gas. Such analyses have mostly been limited to petroleum engineering and geology and have not been conducted by economists.

\section{Environmental Impact Analyses}

The environmental impacts of shale gas development are just as hotly debated as the economic impacts. And since shale gas development is a relatively new phenomenon, scientific studies are ongoing with few results published to date. 
The uncertainty surrounding the environmental impacts of shale gas likely is the main reason for New York's moratorium/ban and for similar actions in other states and regions.

One of the earliest and most controversial of the environmental impact studies claimed that shale gas development creates more lifecycle greenhouse gas emissions than coal development (Howarth, Santoro, and Ingraffea 2011) and that fugitive methane emissions occur during the drilling, fracking, and transporting processes. In a society cognizant of global climate change, this argument caught the attention of the popular press because burning natural gas emits far less carbon dioxide than burning coal. Natural gas was thus considered to be a bridge fuel until technological innovation led to an abundant, less carbon-intensive form of energy creation. The study's claims were later refuted, and recent research suggests that methane emissions from cows (largely from concentrated feed operations) are greater than those from natural gas development (Environmental Protection Agency 2014).

As previously mentioned, another growing concern relates to the potential for hydraulic fracturing to contaminate drinking water and generate seismic activity. According to a recent report from the Natural Resources Defense Council (2012), hydraulic fracturing can contaminate drinking water both on the surface and below ground. Given these fears, it is difficult to parse scientifically tested information from the sheer volume of disinformation (and idle speculation) available on the internet and challenging to keep abreast of the newest research on environmental impacts of shale gas development.

With these issues squarely in the fore, Alan Krupnick and Hal Gordon (2015) offer a paper entitled "What Experts Say about the Environmental Risks of Shale Gas Development." Their study makes a unique contribution to the literature by developing the first survey-based analysis of experts from government agencies, the industry, academia, and nongovernmental organizations to identify the highest-priority environmental risks related to shale gas. The results indicate that the risks of greatest concern include potential contamination of surface water, methane leaks, failed casings and cementing, and damage to habitats. The authors also find that non-industry respondents advocate for the industry taking the lead in mitigating such risks by instituting uniform best practice guidelines while industry respondents indicate that government officials should be responsible for addressing the risks. This research is important because of a prevailing view of tremendous conflict between the natural gas industry and government regulators. Krupnick and Gordon's (2015) study reveals that the two groups' goals are likely more in accord than previously recognized.

\section{Environmental Justice}

Another paper deserving its own subcategory is "Private Contracts as Regulation: A Study of Private Lease Negotiations Using the Texas Natural Gas Industry." In the study, Ashley Vissing (2015) explores factors that drive tractlevel heterogeneity in the quality of mineral leases for owners of the oil and gas rights. This study is truly original in that it addresses issues of environmental justice, among others, associated with shale gas development.

As noted by the author, the study's contribution to the literature is based on the importance of the signed lease, which is the legal contract between extraction firms and mineral-right owners, as the first line of defense protecting households from negative consequences of nearby drilling activities. Negotiation of these 
leases is all but unregulated compared to other phases of the industry's activities. This study is the first to use lease clauses to evaluate the leasing phase and the first to explore the relationship between the racial/ethnic composition of census tracts and the quality of the leases signed by those residents. The results suggest that there is a measurable negative relationship between minority populations and high-quality leases. In other words, subpopulations could potentially be targeted for less-equitable leases and the relatively poor quality of the leases could be caused by information asymmetries, perceived lower opportunity costs, and other mechanisms associated with environmental justice. Therefore, the author suggests that policymakers should consider adopting uniform leasing standards establishing a baseline set of clauses that would be required for all leases of the mineral estate to firms for natural gas extraction.

\section{Policy Analysis}

The last but no less controversial topic covered by this special issue is represented by two studies pertaining to policy formation as a direct result of shale gas development. Policy is appropriate as the last topic of discussion because it encompasses both economic and environmental impacts. Controversy in policy discussions stems from the potential economic benefits of shale gas development in the form of increased tax revenue for some municipalities and/or the state government (Weber, Burnett, and Xiarchos 2014) versus the considerable degree of uncertainty about the short-term and long-term environmental impacts.

In New York, for example, the state placed a temporary moratorium on hydraulic fracturing in 2008. In 2012, the state considered approving limited shale gas development in a southern tier of counties, but the governor's administration instead imposed an indefinite statewide moratorium in 2014 (Kaplan 2014). New York also allows county and municipal governments to institute bans against some or all shale gas activities, including hydraulic fracturing. Several other states have followed suit by allowing full and partial "home rule" moratoria against natural gas development.

In the first policy paper, "Understanding Local Regulation of Fracking: A Spatial Econometric Approach," Patrick Walsh, Stephen Bird, and Martin Heintzelman (2015) use data on local bans and endorsements of shale gas development in New York, local-level census data, and spatial characteristics to conduct a spatial econometric analysis of local fracking policies. They explore the determinants of local regulations on fracking activities in the state. The authors use a spatial probit model because community-level moratoria tend to be clustered geographically. In other words, communities with common borders tend to adopt similar moratoria. The authors argue that the model controls for spatial dependence, which could be caused by a number of unobserved factors. Their regression estimates suggest that several factors are associated with municipalities that implement a local ban or moratorium on fracturing, including the predominant political leaning (percentage of Democrats) and level of education of its residents. The authors find a significant spatial spillover effect across communities, which suggests that adoption of a moratorium or ban by one community will increase the likelihood of adoption of such measures by neighboring communities. The authors also identify several factors that have a negative impact on the likelihood of a community adopting a moratorium or 
ban: the degree of local land development, number of extant conventional oil and gas wells, and the percentage of the community's land area occupied by wetlands.

In the second paper, "I Want In On That: Community-level Policies for Unconventional Gas Development in New York," Nikolaos Zirogiannis, Jessica Alcorn, Jayne Piepenburg, and John Rupp (2015) examine community-level geospatial factors and socio-demographic attributes that explain differences in local policy decisions supporting and opposing unconventional gas development in New York using a spatial ordered probit model. Their findings suggest that New York communities in close proximity to shale gas development in Pennsylvania are more likely to support such development. Communities in which residents predominantly are Democrats and have bachelor's degrees are more likely to adopt policies restricting such activities.

Both of these studies find that the demographic status of an area, as indicated by the predominant level of education and political leaning, influences the likelihood of adoption of a local moratorium. The authors of both studies likewise suggest that policymakers and regulators should investigate the potential negative impacts of shale gas development from an environmental justice perspective. That is, are less-educated communities more likely to be subjected to potential negative impacts from fracking? The underlying implication, also identified by Vissing (2015), is that information asymmetry could potentially lead to inequitable, negative impacts on less affluent communities.

\section{Research Needs and Next Steps}

Although the primary focus of this special issue is unconventional oil and natural gas development, the preceding discussion also applies to conventional fossil fuel development. These papers illustrate the potential insights provided by applying economic theory and empirical approaches to this burgeoning area of research. However, these studies also demonstrate the empirical challenges inherent to shale development research. Categorization of the papers into economic, environmental, and policy analyses is an attempt to formalize the various facets of this new and growing area of economic research.

In particular, the papers in this issue highlight the need for further research. They fill many current gaps in the literature, but considerable ambiguity remains regarding the actual risks associated with the industry. Krupnick and Gordon (2015) identify some of the most critical risks, including potential contamination of surface water, as expressed by a survey of more than 215 experts. Their results imply that the expressed goals of private industry and government experts for mitigating the risks are more in line with one another than previously perceived.

Three of the papers address potential impacts on environmental justice. Vissing's (2015) findings highlight the potential for minority populations to be targeted for poor-quality leases as a result of information asymmetry and/or perceptions of smaller opportunity costs. Her results are echoed by the findings of Walsh, Bird, and Heintzelman (2015) and Zirogiannis et al. (2015), which imply that less-educated communities may be more likely to absorb potential negative impacts from fracking. Those studies suggest that communities in which residents have relatively less education are more supportive of shale gas development, perhaps because residents of low-income areas place a high value on economic opportunity relative to environmental risks. The policy 
studies in this special issue suggest that residents of higher-income areas place greater relative value on the environmental risks and thus adopt policies that restrict hydraulic fracturing. Therefore, New York's moratorium would be justified in the sense that further cost-benefit analyses should be conducted to definitively determine the economic benefits and environmental risks faced by seemingly opposing factions in the state. Nevertheless, all three papers suggest that local and state governments should consider uniform standards for oil and gas leases or at least actively monitor the leasing phase of development, which currently receives the least amount of regulatory oversight.

Another risk identified by these studies is overstated or inflated estimates of positive economic impacts of shale gas development. The accuracy of such estimates is particularly important because policymakers implicitly engage in a cost-benefit analysis when formulating shale gas policies and regulations. If the economic benefits prove to be much smaller than previously estimated, policymakers may no longer be apt to discount the costs of development, including the costs to the environment and human health. And even if policymakers do not overly discount those costs, they may still choose to subsidize the industry through tax exemptions or other favorable policies out of a desire to gain economically in the long run. Wrenn, Kelsey, and Jaenicke (2015) expend considerable effort to accurately (and conservatively) estimate job and wage growth in Pennsylvania. The resulting estimates are roughly half of those calculated previously by Considine, Watson, and Blumsack $(2010,2011)$. Similarly, the study by Cosgrove et al. (2015) exploits New York's moratorium to provide careful estimates of job and wage growth in Pennsylvania using similar job and wage growth in New York as a counterfactual. They find mostly positive economic impacts. However, as in Wrenn, Kelsey, and Jaenicke (2015), their estimates are considerably more moderate than ones from previous studies.

Hedonic price analysis can provide an alternative measure of economic impacts. In well-defined and properly measured models, estimates from a hedonic regression analysis can measure the gross local economic benefits (or costs) associated with shale gas development (Weber, Burnett, and Xiarchos 2014). Two papers in this special issue address current gaps in the literature. Weber and Hitaj (2015) highlight the importance of capturing the effect of severed mineral estates. Jellicoe and Delgado (2015) emphasize the importance of impacts from both active and passive (ex post) development, including gas storage fields, on private real estate values.

Fitzgerald's (2015) research points to the need for further economic analyses of shale gas and oil production. He finds a positive association between production and experience with fracturing but no such association for trade secret protections. These results are important for policymaking. As producers gain from experience, their production processes arguably should require less intensive fracking treatments, which could reduce the risk of environmental damage.

Though not mentioned explicitly in any of the papers in this special issue, the need for economists to engage scientists from other disciplines is clear from the various results reported. Cooperation among disciplines is particularly important now since U.S. policymakers are actively discussing national and state policies and regulations pertaining to unconventional oil and gas development and hydraulic fracturing. Many critics have argued that the federal government should have greater power to regulate the industry since other federal environmental regulations generally are stricter than state regulations. 
For example, some have argued that an extension of the Safe Drinking Water Act would provide leverage to the Environmental Protection Agency in ensuring that states in which enforcement has been lax are protecting their own drinking water resources.

In the absence of federal regulation, some fear a "race to the bottom" in which individual states purposely impose weak regulations to attract natural gas development. According to Glicksman and Levy (2008, p. 13), justifications for federal regulation "reflect commonly understood collective action problems, including negative environmental externalities, resource pooling, the 'race to the bottom,' uniform standards, and the 'NIMBY' (not in my back yard) phenomenon." What is needed in this case, they say, is a model of "cooperative federalism" in which the federal or state government offers guidance regarding the potential environmental impacts from shale gas development but leaves regulation to local governments to provide a more comprehensive, protective, and accountable regulatory framework (Burnett 2013). Conversely, as noted by Krupnick and Gordon (2015), the industry should also take an active role in creating and enforcing best management practices in cooperation with government.

\section{References}

Aguilera, R.F., and M. Radetzki. 2013. "Shale Gas and Oil: Fundamentally Changing Global Energy Markets." Oil and Gas Journal 111(12): 54-61.

British Petroleum. 2014. "BP Statistical Review of World Energy June 2014" (63rd edition). British Petroleum, London, England. Accessed online at www.bp.com/statisticalreview (November 2014).

Burnett, J.W. 2013. "Hydraulic Fracturing and U.S. Water Policy." Global Water Forum. Available at www.globalwaterforum.org/wp-content/uploads/2013/03/Hydraulic-fracturingand-US-water-policy-GWF-1309.pdf (November 2014).

Burnett, J.W., and J.G. Weber. 2014. "Is the Natural Gas Revolution All Its Fracked Up to Be for Local Economies?" Choices Magazine 29(4): 1-5.

Considine, T.J., R. Watson, and S. Blumsack. 2010. "The Economic Impacts of the Pennsylvania Marcellus Shale Natural Gas Play: An Update." Working paper, College of Earth and Mineral Sciences, Pennsylvania State University, University Park.

Considine, T.J., R. Watson, and S. Blumsack. 2011. "The Pennsylvania Marcellus Natural Gas Industry: Status, Economic Impacts, and Future Potential." Working paper, Department of Energy, Environment, and Mineral Economics, Pennsylvania State University.

Cosgrove, B.M., D.R. LaFave, S.T.M. Dissanayake, and M.R. Donihue. 2015. "The Economic Impact of Shale Gas Development: A Natural Experiment along the New York / Pennsylvania Border." Agricultural and Resource Economics Review 44(2): 20-39.

Department of Energy. 2014. "Long Term Applications Received by DOE/FE to Export Domestically Produced LNG from the Lower 48 States." DOE, Washington, DC. Available at www.energy.gov/sites/prod/files/2014/12/f19/Summary\%20of\%20LNG\%20Export\%20 Applications_1.pdf (accessed December 2014).

Energy Information Administration. 2014a. "Petroleum Overview." U.S. Energy Information Administration, Washington, DC. Available at www.eia.gov/totalenergy/data/monthly/ pdf/sec3_3.pdf (accessed December 2014).

2014b. "U.S. Field Production of Crude Oil." U.S. Energy Information Administration, Washington, DC. Available at www.eia.gov/dnav/pet/hist/LeafHandler. ash $\mathrm{x}$ n $=$ PET\&s=MCRFPUS2\&f=A (accessed December 2014).

. 2014c. "U.S. Natural Gas Marketed Production." U.S. Energy Information Administration, Washington, DC. Available at www.eia.gov/dnav/ng/hist/n9050us2a.htm (accessed December 2014).

2014d. "Natural Gas Prices." U.S. Energy Information Administration, Washington, DC. Available at www.eia.gov/dnav/ng/ng_pri_sum_dcu_nus_m.htm (accessed December 2014) 
Environmental Protection Agency. 2011. "Draft Plan to Study the Potential Impacts of Hydraulic Fracturing on Drinking Water Resources." EPA, Washington, DC. Available at www.yosemite.epa.gov (accessed November 2014).

2014. "Inventory of U.S. Greenhouse Gas Emissions and Sinks: 1990-2012." Report 430-R-14-003, EPA, Washington, DC. Available at www.epa.gov/climatechange/Downloads/ ghgemissions/US-GHG-Inventory-2014-Main-Text.pdf (accessed February 2015).

Fitzgerald, T. 2015. "Experiential Gains with a New Technology: An Empirical Investigation of Hydraulic Fracturing." Agricultural and Resource Economics Review 44(2): 83-105.

Friedman, N. 2015. “Oil Hits New Lows, Brent Crude Nears \$50: Brent, U.S. Crude Futures Hit Their Lowest Price since April 2009." Wall Street Journal, January 6. Available at www. wsj.com/articles/oil-prices-extend-declines-1420523070 (accessed January 2015).

Glicksman, R.L., and R.E. Levy. 2008. "A Collective Action Perspective on Ceiling Preemption by Federal Environmental Regulation: The Case of Global Climate Change." Northwestern University Law Review 102(2): 579-648.

Griffin, J.M., and W.S. Neilson. 1994. "The 1985-1986 Price Collapse and Afterwards: What Does Game Theory Add?" Economic Inquiry 32(4): 543-561.

Hill, E.L. 2013. “Unconventional Natural Gas Development and Infant Health: Evidence from Pennsylvania." Working paper 2012-12, Dyson School of Applied Economics and Management, Cornell University.

Howarth, R.W., R. Santoro, and A. Ingraffea. 2011. "Methane and the Greenhouse-gas Footprint of Natural Gas from Shale Formations." Climate Change 106(4): 679-690.

Jellicoe, M., and M.S. Delgado. 2015. "Quantifying the Effects of Underground Natural Gas Storage on Nearby Residents." Agricultural and Resource Economics Review 44(2): 59-82.

Kaplan, T. 2014. "Citing Health Risks, Cuomo Bans Fracking in New York State." New York Times, December 17. Available at www.nytimes.com/2014/12/18/nyregion/cuomo-toban-fracking-in-new-york-state-citing-health-risks.html?smid=tw-bna\&_r=4 (accessed January 2015).

Kinnaman, T.C. 2011. "The Economic Impact of Shale Gas Extraction: A Review of Existing Studies." Ecological Economics 70(7): 1243-1249.

Krupnick, A.J., and H.G. Gordon. 2015. "What the Experts Say about the Environmental Risks of Shale Gas Development." Agricultural and Resource Economics Review 44(2): 106-119.

Macey, G.P., R. Breech, M. Chernaik, C. Cox, D. Larson, D. Thomas, and D.O. Carpenter. 2014. "Air Concentrations of Volatile Compounds near Oil and Gas Production: A Communitybased Exploratory Study." Environmental Health 13(82): 1-18.

MIG, Inc. 2015. "IMPLAN: Empowering the World of Economic Analysis" web page. www.implan. com (accessed May 2015).

Muehlenbachs, L., and A.J. Krupnick. 2013. "Shale Gas Development Linked to Traffic Accidents in Pennsylvania." Common Resources, Resources for the Future, Washington, DC. Available at www.common-resources.org/2013/shale-gas-development-linked-totraffic-accidents-in-pennsylvania (accessed November 2014).

Muehlenbachs, L.A., E. Spiller, and C. Timmins. 2014. "The Housing Market Impacts of Shale Gas Development." Working paper 19796, National Bureau of Economic Research, Cambridge, MA. Available at www.nber.org/papers/w19796 (accessed January 2015).

Munasib, A., and D.S. Rickman. 2015. "Regional Economic Impacts of the Shale Gas and Tight Oil Boom: A Synthetic Control Analysis." Regional Science and Urban Economics 50: 1-17.

Natural Resources Defense Council. 2009. "Unchecked Fracking Threatens Health, Water Supplies" website. www.nrdc.org/energy/gasdrilling (accessed November 2014). NRDC, Washington, DC.

2012. "Water Facts: Hydraulic Fracturing Can Potentially Contaminate Drinking Water Sources." NRDC, Washington, DC. Available at www.nrdc.org/water/files/frackingdrinking-water-fs.pdf (December 2014).

Neuhauser, A. 2014. "Toxic Chemicals, Carcinogens Skyrocket near Fracking Sites." U.S. News and World Report, October 30. Available at www.usnews.com/news/articles/2014/10/30/toxicchemicals-and-carcinogens-skyrocket-near-fracking-sites-study-says (accessed December 2014).

Raimi, D., and R.G. Newell. 2014. "Shale Public Finance: Local Government Revenues and Costs Associated with Oil and Gas Development" website. Duke Energy Initiative Report, Duke University, Durham, NC. Available at www.energy.duke.edu/shalepublicfinance (accessed December 2014).

Ramberg, D.J., and J.E. Parsons. 2012. "The Weak Tie between Natural Gas and Oil Prices." The Energy Journal 33(2): 13-35. 
Robinson, D. 2014. “Business Groups React to New York's Fracking Ban.” Albany Business Review, December 17. Available at www.bizjournals.com/albany/news/2014/12/17/ new-york-to-extend-moratorium-on-fracking.html?page=all (accessed December 2014).

Rosen, S. 1974. "Hedonic Prices and Implicit Markets: Product Differentiation in Pure Competition." Journal of Political Economy 82(1): 34-55.

Schwartz, N.D., C. Krauss, and D. Searcey. 2014. "Sliding Oil and Gas Prices Give Americans More Money to Spend." New York Times, November 13. Available at www.nytimes. com/2014/11/14/business/economy/lower-oil-prices-give-a-lift-to-the-americaneconomy.html (accessed December 2014).

Skoumal, R.J., M.R. Brudzinski, and B.S. Currie. 2015. "Earthquakes Induced by Hydraulic Fracturing in Poland Township, Ohio." Bulletin of the Seismological Society of America, January 6. Available at www.bssaonline.org/content/early/2015/01/01/0120140168. abstract?sid=93c90be0-cb9d-4406-88a9-61031b203c85 (accessed January 2015).

Smith, G. 2014. "U.S. Seen as Biggest Oil Producer after Overtaking Saudi Arabia." Bloomberg News, July 4. Available at www.bloomberg.com/news/2014-07-04/u-s-seen-as-biggestoil-producer-after-overtaking-saudi.html (accessed November 2014).

Solomon, J., and S. Said. 2014. "Why Saudis Decided Not to Prop Up Oil." The Wall Street Journal, December 21. Available at www.wsj.com/articles/why-saudis-decided-not-toprop-up-oil-1419219182 (accessed February 2015).

Vissing, A. 2015. "Private Contracts as Regulation: A Study of Private Lease Negotiations Using the Texas Natural Gas Industry." Agricultural and Resource Economics Review 44(2): 120-137.

Walsh, P.J., S. Bird, and M.D. Heintzelman. 2015. “Understanding Local Regulation of Fracking: A Spatial Econometric Approach." Agricultural and Resource Economics Review 44(2): 138-163.

Weber, J.G. 2012. "The Effects of a Natural Gas Boom on Employment and Income in Colorado, Texas, and Wyoming." Energy Economics 34(5): 1580-1588.

2014. "A Decade of Natural Gas Development: The Makings of a Resource Curse?" Resource and Energy Economics 37: 168-183.

Weber, J.G., J.W. Burnett, and I.M. Xiarchos. 2014. "Shale Gas Development and Housing Values over a Decade: Evidence from the Barnett Shale." Working paper 14-165, U.S. Association for Energy Economics, Cleveland, $\mathrm{OH}$.

Weber, J.G., and C. Hitaj. 2015. "What Can We Learn about Shale Gas Development from Land Values? Opportunities, Challenges, and Evidence from Texas and Pennsylvania." Agricultural and Resource Economics Review 44(2): 40-58.

World Bank. 2014. "World Bank Commodity Price Data (The Pink Sheet)” website. http:// econ.worldbank.org/WBSITE/EXTERNAL/EXTDEC/EXTDECPROSPECTS/0,,contentM DK:21574907 menuPK:7859231 pagePK:64165401 piPK:64165026 theSite PK:476883,00.html (accessed December 2014).

Wrenn, D.H., T.W. Kelsey, and E.C. Jaenicke. 2015. "Resident vs. Nonresident Employment Associated with Marcellus Shale Development." Agricultural and Resource Economics Review 44(2): 1-19.

Zirogiannis, N., J. Alcorn, J. Piepenburg, and J. Rupp. 2015. “I Want In On That: Community-level Policies for Unconventional Gas Development in New York." Agricultural and Resource Economics Review 44(2): 164-194. 